\title{
Reaction kinetic pathway of the recombinant octaprenyl pyrophosphate synthase from Thermotoga maritima: how is it different from that of the mesophilic enzyme
}

\author{
Tun-Hsun Kuo a, Po-Huang Liang a,b,* \\ ${ }^{a}$ Institute of Biochemical Sciences, National Taiwan University, Taipei 10098, Taiwan \\ bInstitute of Biological Chemistry, Academia Sinica, Nankang, Taipei 11529, Taiwan
}

Received 11 April 2002; received in revised form 2 July 2002; accepted 1 August 2002

\begin{abstract}
Octaprenyl pyrophosphate synthase (OPPs) catalyzes the chain elongation of farnesyl pyrophosphate (FPP) via consecutive condensation reactions with five molecules of isopentenyl pyrophosphate (IPP) to generate all-trans $\mathrm{C}_{40}$-octaprenyl pyrophosphate. The polymer forms the side chain of ubiquinone that is involved in electron transport system to produce ATP. Our previous study has demonstrated that Escherichia coli OPPs catalyzes IPP condensation with a rate of $2 \mathrm{~s}^{-1}$ but product release limits the steady-state rate at $0.02 \mathrm{~s}^{-1}$ [Biochim. Biophys. Acta 1594 (2002) 64]. In the present studies, a putative gene encoding for OPPs from Thermotoga maritima, an anaerobic and thermophilic bacterium, was expressed, purified, and its kinetic pathway was determined. The enzyme activity at $25{ }^{\circ} \mathrm{C}$ was $0.005 \mathrm{~s}^{-1}$ under steady-state condition and was exponentially increased with elevated temperature. In contrast to E. coli OPPs, IPP condensation rather than product release was rate limiting in enzyme reaction. The product of chain elongation catalyzed by $T$. maritima OPPs was $\mathrm{C}_{40}$ and the rate of its conversion to $\mathrm{C}_{45}$ was negligible. Under single-turnover condition with $10 \mu \mathrm{M}$ OPPs.FPP complex and $1 \mu \mathrm{M}$ IPP, only the $\mathrm{C}_{20}$ was formed rather than $\mathrm{C}_{20}-\mathrm{C}_{40}$ observed for $E$. coli enzyme. Together, our data suggest that the thermophilic OPPs from T. maritima has lower enzyme activity at $25{ }^{\circ} \mathrm{C}$, higher product specificity, higher thermal stability and lower structural flexibility than its mesophilic counterpart from $E$. coli.
\end{abstract}

(C) 2002 Elsevier Science B.V. All rights reserved.

Keywords: Prenyltransferase; Ubiquinone; Single-turnover; Thermophile; Mesophile

\section{Introduction}

Thermophiles are organisms that can grow under high temperature conditions $\left(>50{ }^{\circ} \mathrm{C}\right)$. Proteins in thermophiles are heat resistant and maintain proper three-dimensional structure even at extremely high temperatures, allowing the organism to survive the harsh environment. However,

Abbreviations: OPPs, octaprenyl pyrophosphate synthase; OPP, octaprenyl pyrophosphate; FPP, farnesyl pyrophosphate; IPP, isopentenyl pyrophosphate; PCR, polymerase chain reaction; IPTG, isopropyl- $\beta$-Dthiogalactopyranoside; Ni-NTA, nickel nitrilo-tri-acetic acid; Tris, tris(hydroxymethyl)aminomethane; Hepes, 4-(2-hydroxyethyl)-1-piperazineethanesulfonic acid; EDTA, ethylenediaminetetraacetic acid; SDS-PAGE, sodium dodecyl sulfate-polyacrylamide gel electrophoresis; TLC, thin layer chromatography; MW, molecular weight

Corresponding author. Institute of Biological Chemistry, Academia Sinica, Nankang, Taipei 11529, Taiwan. Tel.: +886-2-2785-5696x6070; fax: +886-2-2788-9759.

E-mail address: phliang@gate.sinica.edu.tw (P.-H. Liang). little is known about how the proteins of a thermophile differ from those of a mesophile to account for their thermostability. Sequence comparisons show that hyperthermophilic and mesophilic versions of the same enzyme typically share about $30-50 \%$ identity [1]. Even the crystal structure for a hyperthermophilic rubredoxin containing only 53 amino acids from the archaebacterium Pyrococcus furiosus shows that it is virtually superimposable on its mesophilic counterpart [2]. The relatively minor changes in protein structure apparently enhance packing via additional interactions such as salt bridges and hydrogen bonds.

In this study, a putative octaprenyl pyrophosphate synthase (OPPs) identified from Thermotoga maritima genome by sequence comparison (Fig. 1) was chosen as the model system to examine the activity, product specificity, thermal stability and structural flexibility of the enzyme in comparison with its mesophilic counterpart from Escherichia coli. T. maritima was originally isolated from geothermal heated marine sediment at Vulcano, Italy. This organism is an 

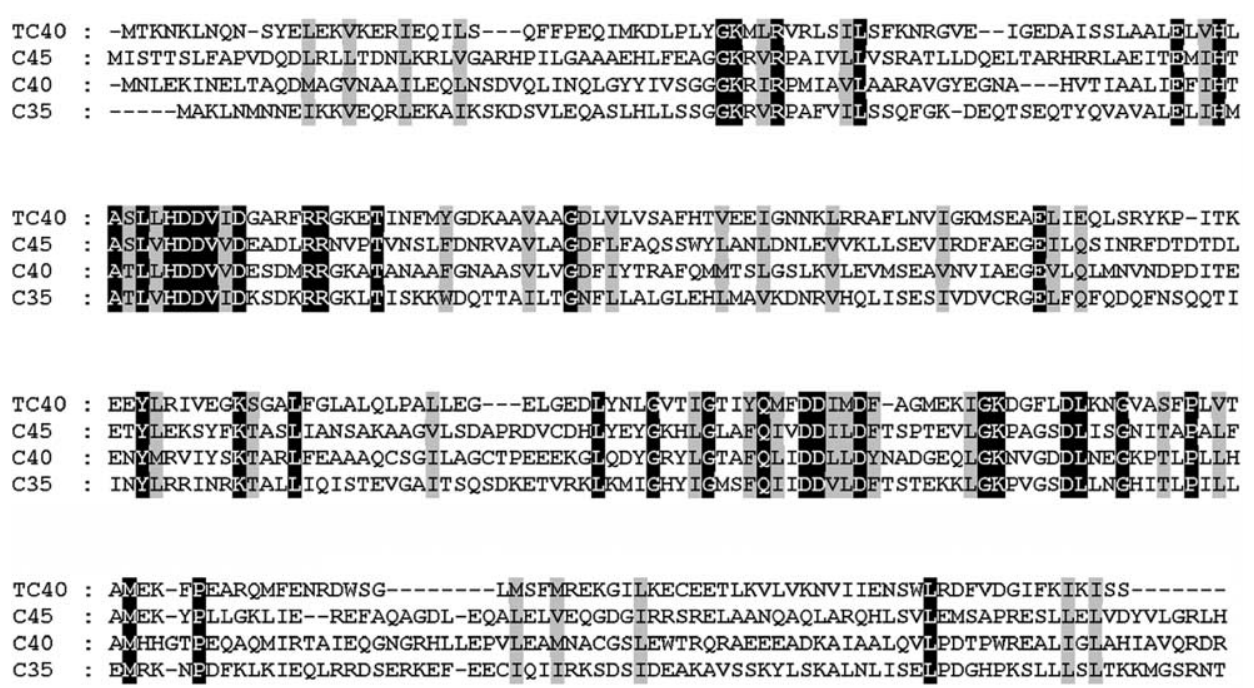

Fig. 1. Alignment of T. maritima OPPs (TC40) sequence with that of E. coli OPPs (C40), Synechocystis sp. solanesyl pyrophosphate synthase (C45) and M. tuberculosis heptaprenyl pyrophosphate synthase (C35). Black and gray outlines indicate identical and similar amino acid residues, respectively.

anaerobic bacterium and has optimum growth temperature of $80{ }^{\circ} \mathrm{C}$ [3]. OPPs belongs to a prenyltransferase family that catalyzes the chain elongation of allylic pyrophosphate via condensation with IPP $[4,5]$. As shown in Scheme 1, the enzyme catalyzes the condensation reactions of farnesyl pyrophosphate (FPP) with five molecules of isopentenyl pyrophosphate (IPP) to produce $\mathrm{C}_{40}$ octaprenyl pyrophosphate (OPP) [6,7]. OPPs is responsible for the biosynthesis of ubiquinone side chain in E. coli $[8,9]$. Other organisms contain ubiquinone with designate lengths of side chain synthesized by specific prenyltrasnferases [10]. For example, the lengths of ubiquinone side chain are $\mathrm{C}_{30}$ for yeast $S$. cerevisiae, $\mathrm{C}_{45}$ for rat and $\mathrm{C}_{50}$ for human, which are synthesized by hexaprenyl pyrophosphate synthase, solanesyl pyrophosphate synthase and decaprenyl pyrophosphate

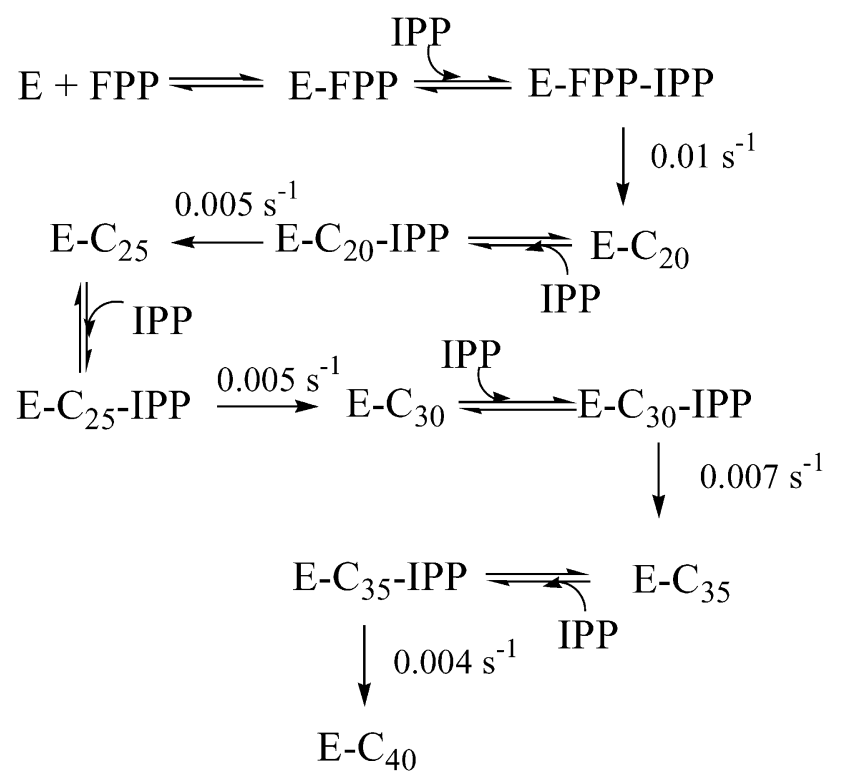

Scheme 1. The kinetic scheme proposed for T. maritima OPPs reaction. synthase, respectively [11-13]. We had studied the OPPs in $E$. coli and found that the enzyme generated products longer than $\mathrm{C}_{40}$ [14]. However, the rate constant $\left(0.02 \mathrm{~s}^{-1}\right)$ for formation of the product with additional IPP condensation is 100 -fold smaller than that $\left(2 \mathrm{~s}^{-1}\right)$ for $\mathrm{C}_{40}$ production. Moreover, under the condition with $E$. coli OPPs.FPP $(10 \mu \mathrm{M})$ in much excess of IPP $(1 \mu \mathrm{M}), \mathrm{C}_{20}-\mathrm{C}_{40}$ rather than $\mathrm{C}_{20}$ alone were generated [14]. This may be due to a higher IPP affinity of OPPs-intermediate relative to OPPs.FPP, a property reflecting the flexible protein conformation [15]. We report in this paper the characterization of a recombinant OPPs from T. maritima focusing on its reaction kinetics, product specificity, thermal stability and structural flexibility.

\section{Materials and methods}

\subsection{Chemicals}

$\left[{ }^{14} \mathrm{C}\right] \mathrm{IPP}(55 \mathrm{mCi} / \mathrm{mmol})$ radiolabeled substrate was purchased from Amersham Pharmacia Biotech and FPP was product of Sigma Co. Reverse phase TLC for product analysis was obtained from Merck (Darmstadt, Germany). The plasmid mini-prep kit, DNA gel extraction kit and NiNTA were the products of QIAGEN. Potato acidic phosphatase (2 Unit/mg) was purchased from Boehringer Mannheim. The pET-32Xa/LIC vector, competent cells E. coli JM109 and BL21 (DE3), T4 DNA polymerase, and Factor Xa were obtained from Novagen. All other buffer and reagents were of the highest commercial purity. Millipore ultrapure $\mathrm{H}_{2} \mathrm{O}$ was used in all experiments.

\subsection{Overexpression of OPPs from T. maritima}

T. maritima obtained from American type culture collection (ATCC) was grown at $80{ }^{\circ} \mathrm{C}$ under anaerobic con- 
dition in the medium prepared according to protocol provided by ATCC. The genomic DNA was obtained from the harvested cells using DNA extraction kit according to manufacturer's instruction. Using its genomic DNAs as template, the gene encoding OPPs from the bacterium was amplified by carrying out polymerase chain reaction (PCR). The forward primer $5^{\prime}$ ATGACGAAAAACAAGCTGAACCAA $3^{\prime}$ and reverse primer $5^{\prime}$ TCATGAAGAGATTTTGATTTTAAA $3^{\prime}$ were utilized in the PCR. The PCR product (OPPs gene) was purified from $0.8 \%$ agarose gel electrophoresis and used as a template for the second PCR to create FXa cleavage site and the complementary sequences for the vector pET-32Xa/LIC. In this PCR reaction, the forward primer $5^{\prime}$ GGTATTGAGGGTCGCATGACGAAAAACAAG $3^{\prime}$ and the reverse primer 5' AGAGGAGAGTTAGAGCCTCATGAAGAGATT 3' were employed. The DNA product was ligation with the vector and transformed into E. coli BL21 (DE-3) for protein expression as previously described [14].

\subsection{Purification of recombinant T. maritima OPPS}

The purification procedure of recombinant T. maritima OPPs was the same as previously reported for E. coli OPPs [14]. The cell lysate was loaded onto a Ni-NTA column and the protein with His tag was finally eluted with $25 \mathrm{mM}$ Tris (pH 7.5), $150 \mathrm{mM} \mathrm{NaCl}$ and $300 \mathrm{mM}$ imidazole. The protein solution was dialyzed twice against 21 buffer ( $25 \mathrm{mM}$ Tris, $\mathrm{pH} 7.5$, and $150 \mathrm{mM} \mathrm{NaCl})$ and digested with FXa to remove tag. The untagged protein was separated from the tag by loading onto a Ni-NTA column. The tag was bound to Ni-NTA and the OPPs eluted by a buffer of $25 \mathrm{mM}$ Tris, $\mathrm{pH} 7.5,5 \mathrm{mM}$ imidazole and $150 \mathrm{mM} \mathrm{NaCl}$ was highly pure according to SDSPAGE analysis.

\subsection{Steady-state $K_{m}$ and $k_{\text {cat }}$ measurements}

The OPPs reaction was initiated by adding $0.1 \mu \mathrm{M}$ enzyme (final concentration) to a mixture containing various concentrations of FPP $(1-10 \mu \mathrm{M})$ and $\left[{ }^{14} \mathrm{C}\right] \mathrm{IPP}$ $(1-50 \mu \mathrm{M})$ in $100 \mathrm{mM}$ Hepes buffer (pH 7.5), $50 \mathrm{mM}$ $\mathrm{KCl}$ and $0.5 \mathrm{mM} \mathrm{MgCl}{ }_{2}$ at $25{ }^{\circ} \mathrm{C}$. The enzyme concentration used in all experiments was determined from its absorbance at $280 \mathrm{~nm}$ (extinction coefficient $=20340 \mathrm{M}^{-1}$ $\mathrm{cm}^{-1}$ ). Within $10 \%$ substrate depletion, the reaction mixture was periodically withdrawn. The reaction was terminated by adding $10 \mathrm{mM}$ (final concentration) EDTA and the product was extracted with 1-butanol. The product was quantitated by counting the radioactivity in butanol phase $\left(\left[{ }^{14} \mathrm{C}\right] \mathrm{IPP}\right.$ was in aqueous phase) using a Beckmann LS6500 scintillation counter. The OPPs steadystate $k_{\text {cat }}$ was calculated based on the rate of IPP consumption. The initial rate was calculated by plotting the [IPP] consumed versus time and the kinetic constants were obtained by fitting the data with the Michaelis-
Menten equation using KaleidaGraph computer software (synergy software).

\subsection{Temperature dependence of OPPs activity}

The activity was measured as described above in a reaction mixture containing $0.1 \mu \mathrm{M}$ OPPs, $5 \mu \mathrm{M}$ FPP, 50 $\mu \mathrm{M}\left[{ }^{14} \mathrm{C}\right] \mathrm{IPP}$ in a buffer of $100 \mathrm{mM}$ Hepes $(\mathrm{pH} 7.5), 0.5$ $\mathrm{mM} \mathrm{MgCl}_{2}$ and $50 \mathrm{mM} \mathrm{KCl}$ at temperature ranging from 25 to $85{ }^{\circ} \mathrm{C}$. The enzyme was added to a preheated mixture to initiate the reaction. The initial rate in the first $5 \mathrm{~min}$ of reaction was measured at each temperature.

\subsection{Single-turnover experiments}

The single-turnover reaction was initiated by mixing 15 $\mu \mathrm{l}$ of the enzyme $(10 \mu \mathrm{M})$ preincubated with FPP $(2 \mu \mathrm{M})$ with equal volume of $\left[{ }^{14} \mathrm{C}\right] \mathrm{IPP}(50 \mu \mathrm{M})$ solution in buffer containing $100 \mathrm{mM}$ Hepes (pH 7.5), $0.5 \mathrm{mM} \mathrm{MgCl}$ and $50 \mathrm{mM} \mathrm{KCl}$ at $25{ }^{\circ} \mathrm{C}$. The concentrations cited in the parentheses and hereafter in the paper are those after mixing. The reaction mixture quenched with EDTA in specified time period was extracted with the same volume of 1-butanol and the radioactivity in the organic phase (intermediates and product) was counted by the scintillation counter (Beckmann LS6500). For identification of intermediates and product at each time point, the radiolabeled polyprenyl pyrophosphates were extracted with 1butanol and treated with $20 \%$ propanol, $4.4 \mathrm{U} / \mathrm{ml}$ acidic phosphatase, $0.1 \%$ Triton $\mathrm{X}-100$ and $50 \mathrm{mM}$ sodium acetate $(\mathrm{pH} 4.7)$ to be converted to the corresponding polyprenols [16]. The products were separated by reverse phase TLC with acetone/water (19:1) as mobile phase and the product distribution was determined by autoradiography [17]. The time course for each intermediate was simulated by KINSIM computer program as described below.

\subsection{Data simulation}

The KINSIM program [18] simulation of the kinetic data presented in this paper is as described in our previous report [14]. The derived kinetic pathway of the T. maritima OPPs reaction is shown in Scheme 1 and the details of the kinetic simulation of the data are shown in Chart 1.

\subsection{OPPs molecular weight determination}

The molecular weight of the recombinant OPPs was determined by size-exclusion chromatography on a Blue Dextran 2000 calibrated pre-packed Sephadex G-200 column $(1 \times 20 \mathrm{~cm}$, Amsheram Pharmacia Biotech). The molecular weight was estimated from the plot of $K_{\mathrm{av}}$ vs. $\log$ MW of protein molecular weight standards, which were catalase $(206,000)$, aldolase $(170,000)$, bovine serum 


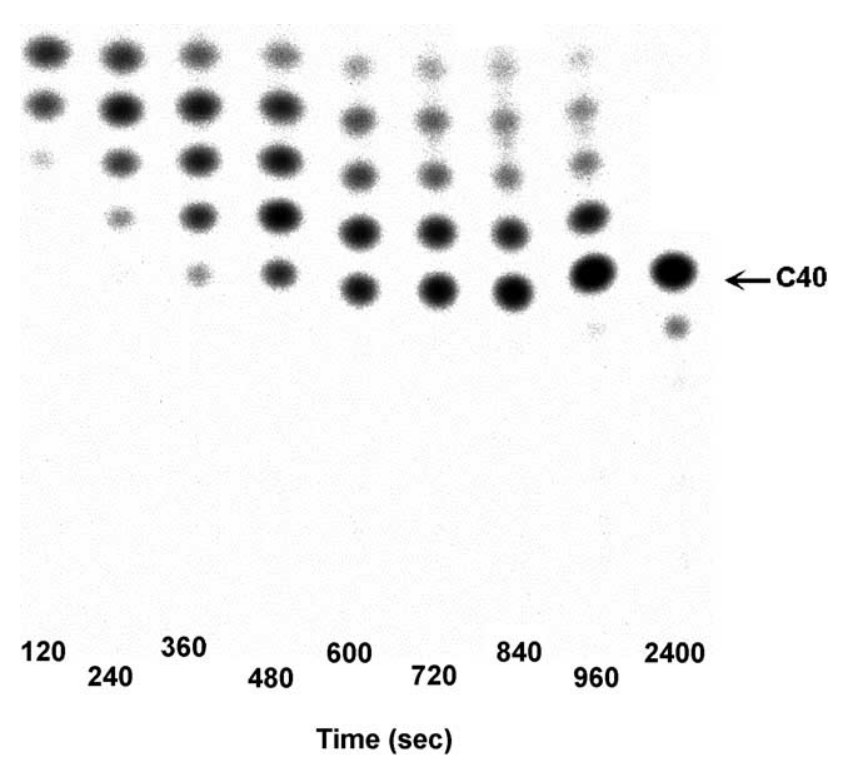

Plate 1. The intermediates and product formed during the T. maritima OPPs single-turnover reaction with $10 \mathrm{mM}$ enzyme, $2 \mathrm{mM} \mathrm{FPP}$ and $50 \mathrm{mM}$ $\left[{ }^{14} \mathrm{C}\right] \mathrm{IPP}$ at $\mathrm{pH} 7.5$ and $25^{\circ} \mathrm{C}$. The reaction continued for 120 to $960 \mathrm{~s}$ and an extended period of $2400 \mathrm{~s}$.

albumin (67,000), and ovalbumin $(43,000)$. A buffer containing $25 \mathrm{mM}$ Tris ( $\mathrm{pH} 7.5)$ and $150 \mathrm{mM} \mathrm{NaCl}$ was used to elute the proteins at a flow rate of $0.5 \mathrm{ml} / \mathrm{min}$. The $K_{\mathrm{av}}$ values were calculated using the equation $K_{\mathrm{av}}=\left(V_{\mathrm{e}}-V_{\mathrm{o}}\right) /$ $\left(V_{\mathrm{t}}-V_{\mathrm{o}}\right)$ where $V_{\mathrm{e}}$ is elution volume of the protein, $V_{\mathrm{o}}$ is the elution volume of Blue Dextran 2000 and $V_{\mathrm{t}}$ is total gel bed volume [19].

\subsection{Circular dichroism (CD) experiments}

For determination of secondary structure of T. maritima and $E$. coli OPPs enzymes, CD measurements were made on a Jasco J-710 spectrophotometer in a $0.1 \mathrm{~cm}$ water-jacketed cuvette. The ellipticity of 200- $\mu$ l sample containing $1 \mu \mathrm{M}$ OPPs in a buffer of $25 \mathrm{mM}$ Tris $(\mathrm{pH} 7.5)$ and $150 \mathrm{mM} \mathrm{NaF}$ $25{ }^{\circ} \mathrm{C}$ was recorded from 200 to $260 \mathrm{~nm}$. Spectra reported were the average of three scans collected at $30 \mathrm{~nm} / \mathrm{min}$ with a 2-s response time. The secondary structure of the protein was analyzed using the program SELCON2 [20]. For the measurement of thermal stability, the ellipticity of $10 \mu \mathrm{M}$ enzyme was monitored at $208 \mathrm{~nm}$ and the temperature was increased at a rate of $30{ }^{\circ} \mathrm{C} / \mathrm{h}$. Thermal unfolding curve of $E$. coli OPPs was fitted with a two-state unfolding model [21].

\subsection{Final product distribution}

The reaction mixture containing different concentrations of OPPs, $\left[{ }^{14} \mathrm{C}\right] \mathrm{IPP}$ and FPP in buffer of $100 \mathrm{mM}$ Hepes buffer ( $\mathrm{pH} 7.5$ ), $0.5 \mathrm{mM} \mathrm{MgCl}_{2}$ and $50 \mathrm{mM} \mathrm{KCl}$, was incubated at $25{ }^{\circ} \mathrm{C}$ for $100 \mathrm{~h}$. The reaction was terminated with $10 \mathrm{mM}$ EDTA. We then extracted the products with 1butanol, evaporated the solvent under $\mathrm{N}_{2}$, converted the products to polyprenols and analyzed the polyprenols by TLC as described above.

\section{Results}

3.1. Temperature dependence of the T. maritima OPPs activity and the $T_{m}$ value

The $k_{\text {cat }}$ value of recombinant OPPs of T. maritima is $0.005 \mathrm{~s}^{-1}$ and FPP and IPP $K_{\mathrm{m}}$ values are 1.5 and $2 \mu \mathrm{M}$, respectively, at $25{ }^{\circ} \mathrm{C}$ and $\mathrm{pH} 7.5$. The enzyme activities at temperatures ranging from 25 to $85{ }^{\circ} \mathrm{C}$ exponentially increased with elevated temperature (Fig. 2A). According to Arrhenius equation, the activation energy $\left(E_{\mathrm{a}}\right)$ required for the reaction is calculated to be $16.2 \mathrm{kcal} / \mathrm{mol}$. Measured by $\mathrm{CD}$ spectrophotometer, the temperature at which $T$. maritima OPPs is half-folded $\left(T_{\mathrm{m}}\right)$ is $>80{ }^{\circ} \mathrm{C}$, higher than that of $E$. coli enzyme $\left(55.3{ }^{\circ} \mathrm{C}\right)$, indicating that $T$. maritima OPPs has higher thermal stability (Fig. 2B).
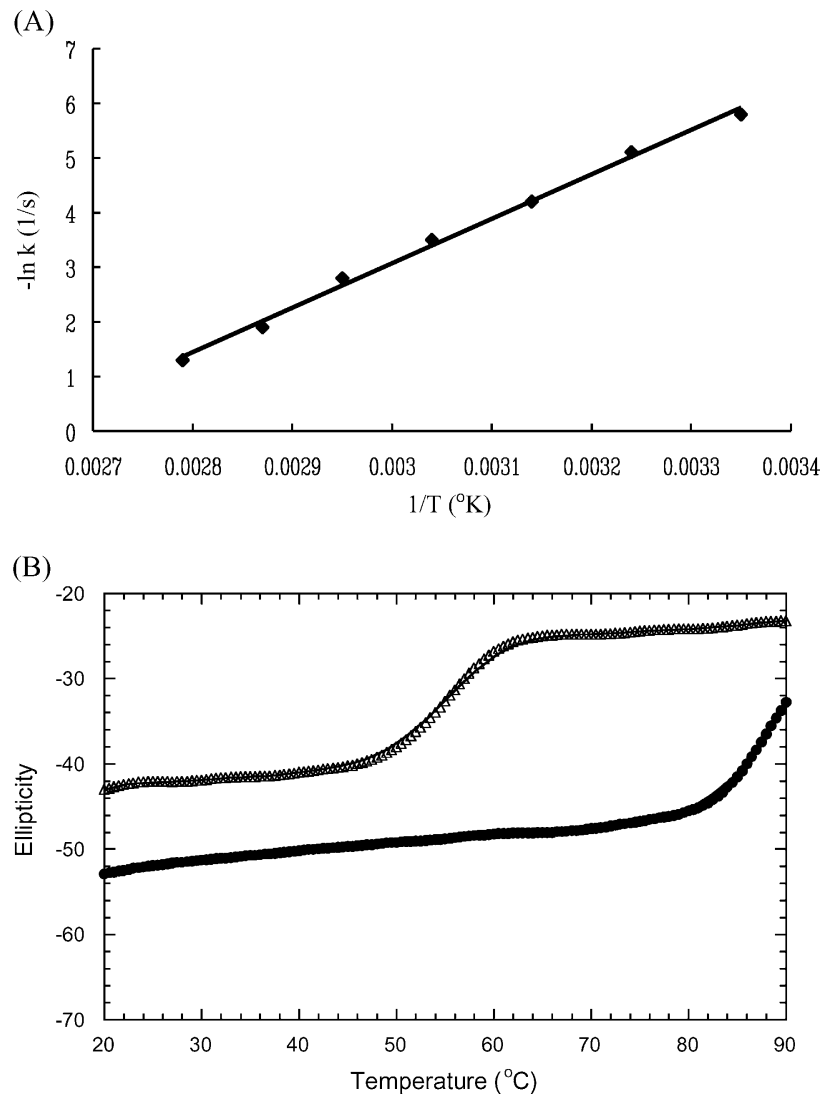

Fig. 2. (A) T. maritima OPPs activity measured at different temperature. The initial rate in the first $5 \mathrm{~min}$ of the enzyme reaction of $0.1 \mu \mathrm{M}$ enzyme with $5 \mu \mathrm{M}$ FPP and $50 \mu \mathrm{M}\left[{ }^{14} \mathrm{C}\right] \mathrm{IPP}$ was measured at temperature ranging from 25 to $85{ }^{\circ} \mathrm{C}$. (B) Thermal stabilities of recombinant OPPs from E. coli and $T$. maritima monitored by CD. The ellipticity at $208 \mathrm{~nm}$ was monitored from 25 to $90{ }^{\circ} \mathrm{C}$ using $10 \mu \mathrm{M}$ E. coli OPPs $(\triangle)$ and $10 \mu \mathrm{M}$ T. maritima enzyme (๑) The half-folded $T_{\mathrm{m}}$ was $55.3{ }^{\circ} \mathrm{C}$ for $E$. coli enzyme by fitting the data with a two-state unfolding model. For T. maritima OPPs, the unfolding was not completed at $90{ }^{\circ} \mathrm{C}$. 


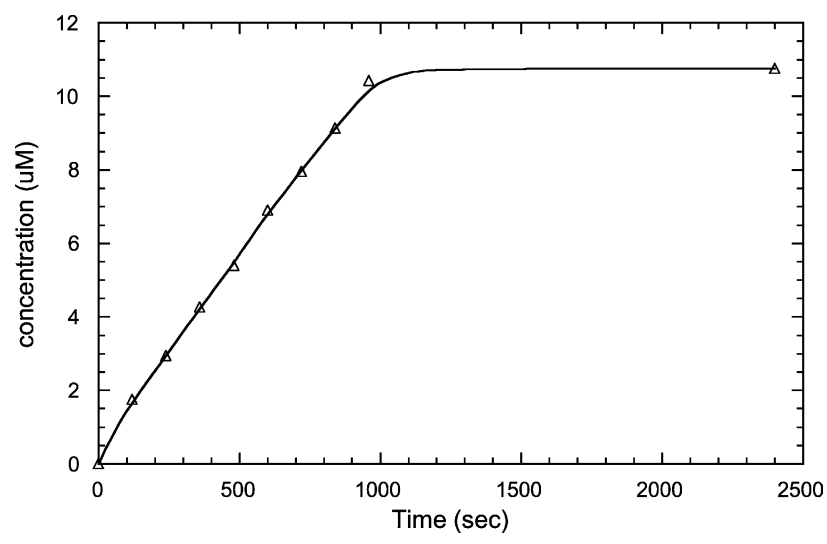

Fig. 3. The single-turnover reaction of T. maritima OPPs with enzyme in excess of FPP. A solution containing enzyme $(10 \mu \mathrm{M})$ preincubated with FPP $(2 \mu \mathrm{M})$ was mixed with $\left[{ }^{14} \mathrm{C}\right] \mathrm{IPP}(50 \mu \mathrm{M})$ at $\mathrm{pH} 7.5$ and $25{ }^{\circ} \mathrm{C}$. The products of IPP condensation formed at each time point were quantitated by scintillation counting of the radioactivity in the butanol layer. The curve represents a fit by KINSIM simulation using rate constants shown in Scheme 1 .

\subsection{Complete kinetic pathway of T. maritima OPPS}

Due to the great hydrophobicity of the product, the reaction rates of the long-chain polyprenyl synthetic enzymes are often limited by slow product release under steady-state condition [14,22,23]. The 3-D structure of the $\mathrm{C}_{55}$-undecaprenyl pyrophosphate synthase implicates the strong hydrophobic interactions between the enzyme and the product and provides a rationale for the slow product release [24]. In order to measure the IPP condensation rate constant, we have to perform the single-turnover experiments with higher enzyme concentration than the substrate

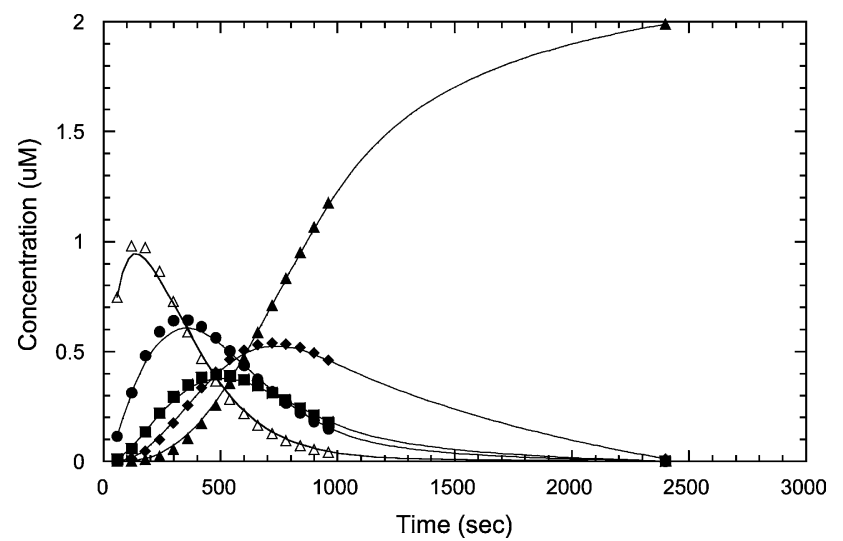

Fig. 4. Single-turnover time courses of intermediates $\left(\mathrm{C}_{20}-\mathrm{C}_{35}\right)$ and product $\left(\mathrm{C}_{40}\right)$ in OPPs reaction. T. maritima OPPs enzyme $(10 \mu \mathrm{M})$ preincubated with FPP $(2 \mu \mathrm{M})$ was mixed with $\left[{ }^{14} \mathrm{C}\right] \mathrm{IPP}(50 \mu \mathrm{M})$ at $\mathrm{pH} 7.5$ and $25{ }^{\circ} \mathrm{C}$. The data represent the time courses of $\mathrm{C}_{20}(\Delta), \mathrm{C}_{25}(\bullet), \mathrm{C}_{30}$ $(\boldsymbol{\bullet}), \mathrm{C}_{35}(\diamond)$ and $\mathrm{C}_{40}(\boldsymbol{\Delta})$. The fitting curves were obtained from KINSIM simulation using the kinetic pathway shown in Scheme 1.

FPP so that product release is not limiting the reaction rate $[14,22,23]$. The formation of $\mathrm{C}_{20}-\mathrm{C}_{40}$ catalyzed by $T$. maritima OPPs was examined during the enzyme singleturnover reaction containing $10 \mu \mathrm{M}$ enzyme, $2 \mu \mathrm{M}$ FPP and $50 \mu \mathrm{M}\left[{ }^{14} \mathrm{C}\right] \mathrm{IPP}$. The total formation of radiolabeled species with time in the reaction is shown in Fig. 3. Since the percentages of $\mathrm{C}_{20}-\mathrm{C}_{40}$ at each time point of the reaction were obtained by imaging as shown in Plate 1 , the time courses of these intermediates could be determined (Fig. 4). The data were fitted using KINSIM program to obtain rate constant for individual IPP condensation catalyzed by OPPs. The derived kinetic pathway of T. maritima OPPs reaction is summarized in Scheme 1. The fit of the total IPP incorpo-

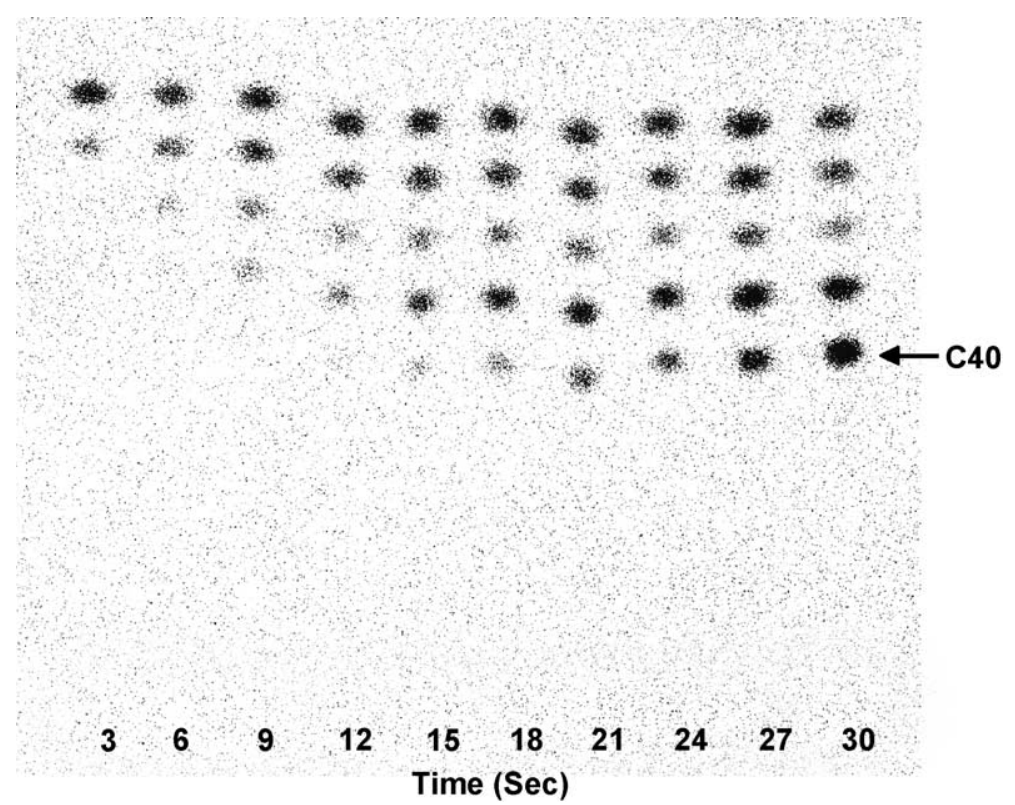

Plate 2. The intermediates and product formed during the T. maritima OPPs single-turnover reaction with $10 \mathrm{mM}$ enzyme, $2 \mathrm{mM} \mathrm{FPP}$ and $50 \mathrm{mM}\left[{ }^{14} \mathrm{C}\right] \mathrm{IPP}$ at $\mathrm{pH} 7.5$ and $80{ }^{\circ} \mathrm{C}$. The reaction time was from 3 to $30 \mathrm{~s}$. The $\mathrm{C}_{40}$ product was formed much earlier than the same reaction performed at $25{ }^{\circ} \mathrm{C}$. 


$$
\begin{aligned}
& \mathrm{E}+\mathrm{S} \underset{\mathrm{k}_{-1}}{\stackrel{\mathrm{k}_{1}}{\rightleftharpoons}} \mathrm{ES} \quad \mathrm{ES}+\mathrm{I} \underset{\mathrm{k}_{-2}}{\stackrel{\mathrm{k}_{2}}{\rightleftharpoons}} \mathrm{ESI} \quad \mathrm{ESI} \underset{\mathrm{k}_{-3}}{\stackrel{\mathrm{k}_{3}}{\rightleftharpoons}} \mathrm{EK} \quad \mathrm{EK}+\mathrm{I} \underset{\mathrm{k}_{-4}}{\stackrel{\mathrm{k}_{4}}{\rightleftharpoons}} \mathrm{EKI} \\
& \mathrm{EKI} \underset{\mathrm{k}_{-5}}{\stackrel{\mathrm{k}_{5}}{\rightleftharpoons}} \mathrm{EL} \quad \mathrm{EL}+\mathrm{I} \underset{\mathrm{k}_{-6}}{\stackrel{\mathrm{k}_{6}}{\rightleftharpoons}} \mathrm{ELI} \quad \mathrm{ELI} \underset{\mathrm{k}_{-7}}{\stackrel{\mathrm{k}_{7}}{\rightleftharpoons}} \mathrm{EM} \quad \mathrm{EM}+\mathrm{I} \underset{\mathrm{k}_{-8}}{\stackrel{\mathrm{k}_{8}}{\rightleftharpoons}} \mathrm{EMI} \\
& \mathrm{EM}_{\mathrm{k}_{-9}}^{\stackrel{\mathrm{k}_{9}}{\rightleftharpoons}} \mathrm{EN} \quad \mathrm{EN}+\mathrm{I} \underset{\mathrm{k}_{-10}}{\stackrel{\mathrm{k}_{10}}{\rightleftharpoons}} \mathrm{ENI} \quad \mathrm{ENI} \underset{\mathrm{k}_{-11}}{\stackrel{\mathrm{k}_{11}}{\rightleftharpoons}} \mathrm{EP} \quad \mathrm{EP} \underset{\mathrm{k}_{-12}}{\stackrel{\mathrm{k}_{12}}{\rightleftharpoons}} \mathrm{E}+\mathrm{P} \\
& \mathrm{E}=\text { enzyme; } \mathrm{I}=\mathrm{IPP} ; \mathrm{S}=\mathrm{C}_{15}-\mathrm{FPP} ; \mathrm{K}=\mathrm{C}_{20} ; \mathrm{L}=\mathrm{C}_{25} ; \mathrm{M}=\mathrm{C}_{30} ; \mathrm{N}=\mathrm{C}_{35} ; \mathrm{P}=\mathrm{C}_{40} \text {; }
\end{aligned}
$$

Rate constants

$$
\begin{aligned}
& \mathrm{k}_{1}=10 \mu \mathrm{M}^{-1} \mathrm{~s}^{-1} \quad \mathrm{k}_{-1}=15 \mathrm{~s}^{-1} \quad \mathrm{k}_{2}=10 \mu \mathrm{M}^{-1} \mathrm{~s}^{-1} \quad \mathrm{k}_{-2}=20 \mathrm{~s}^{-1} \quad \mathrm{k}_{3}=0.01 \mathrm{~s}^{-1} \quad \mathrm{k}_{-3}=0 \mathrm{~s}^{-1} \\
& \mathrm{k}_{4}=10 \mu \mathrm{M}^{-1} \mathrm{~s}^{-1} \quad \mathrm{k}_{-4}=20 \mathrm{~s}^{-1} \quad \mathrm{k}_{5}=0.005 \mathrm{~s}^{-1} \quad \mathrm{k}_{-5}=0 \mathrm{~s}^{-1} \quad \mathrm{k}_{6}=10 \mu \mathrm{M}^{-1} \mathrm{~s}^{-1} \quad \mathrm{k}_{-6}=20 \mathrm{~s}^{-1} \\
& \mathrm{k}_{7}=0.005 \mathrm{~s}^{-1} \mathrm{k}_{-7}=0 \mathrm{~s}^{-1} \quad \mathrm{k}_{8}=10 \mu \mathrm{M}^{-1} \mathrm{~s}^{-1} \quad \mathrm{k}_{-8}=20 \mathrm{~s}^{-1} \quad \mathrm{k}_{9}=0.007 \mathrm{~s}^{-1} \quad \mathrm{k}_{-9}=0 \mathrm{~s}^{-1} \\
& \mathrm{k}_{10}=10 \mu \mathrm{M}^{-1} \mathrm{~s}^{-1} \quad \mathrm{k}_{-10}=20 \mathrm{~s}^{-1} \mathrm{k}_{11}=0.004 \mathrm{~s}^{-1} \mathrm{k}_{-11}=0 \mathrm{~s}^{-1} \quad \mathrm{k}_{12}=15 \mathrm{~s}^{-1} \quad \mathrm{k}_{-12}=10 \mu \mathrm{M}^{-1} \mathrm{~s}^{-1}
\end{aligned}
$$

Chart 1. Kinetic constants used to simulate the time course of T. maritime OPPs single-turnover reaction.

ration with time during the single-turnover reaction (Fig. 3) is obtained by using these kinetic constants to sum up all the intermediates in each specified time period of reaction. As shown in Scheme 1, the rate constant determined for each of the five IPP condensation steps leading to $\mathrm{C}_{40}$ product formation is approximately the same $\left(\sim 0.005 \mathrm{~s}^{-1}\right)$ according to KINSIM simulation. Because this rate constant equals to the steady-state $k_{\text {cat }}$ value, the IPP condensation represents the rate-limiting step of the $T$. maritima OPPs reaction. In contrast, the IPP condensation rate constant $(2$ $\mathrm{s}^{-1}$ ) of $E$. coli OPPs is $10^{3}$ times larger at $25^{\circ} \mathrm{C}$. However, at $80{ }^{\circ} \mathrm{C}$, the $T$. maritima OPPs activity is greatly enhanced (Plate 2), consistent with the predicted increase of IPP condensation rate. This indicates that at high temperature, the IPP condensation is still a rate-limiting step for $T$. maritima enzyme.

\subsection{Composition and secondary structure of T. maritima OPPS}

In order to search for the possible cause of the significant reduction of OPPs activity at room temperature, we performed gel filtration chromatography to determine the composition of $T$. maritima OPPs and found that the enzyme is a dimer (data not shown). E. coli OPPs also is a dimeric enzyme and its dimerization is essential for product chain length determination [25]. Furthermore, the secondary structure of $T$. maritima OPPs measured using CD spectrophotometer is compared to that of $E$. coli enzyme. As shown in Fig. 5, both CD spectra are similar with the $\alpha$ helix and $\beta$ sheet contents of $52 \%$ and $23 \%$ for $E$. coli OPPs, and $59 \%$ and $26 \%$ for $T$. maritima OPPs, respectively, indicating the similar secondary structure for the two enzymes.

\subsection{Product distribution of OPPs reaction}

From the data presented above, under single-turnover condition $\mathrm{C}_{40}$ is the exclusive product of $T$. maritima OPPs reaction. We had further examined the enzyme final prod-

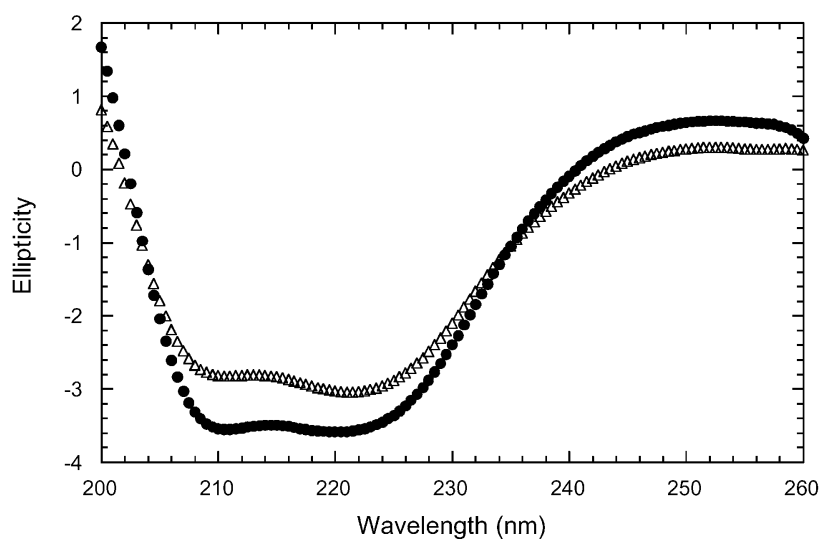

Fig. 5. Analysis of secondary structures of T. maritima and E. coli OPPs enzymes using CD. The ellipticities of $1 \mu \mathrm{M} \mathrm{E}$. coli enzyme $(\triangle)$ and $1 \mu \mathrm{M}$ T. maritima enzyme (•) were recorded from 200 to $260 \mathrm{~nm}$. Two enzymes have similar secondary structure according to their $\mathrm{CD}$ spectra. 
ucts after a long-time incubation (100 h) under a variety of different conditions. The results are shown in Fig. 6 and the quantitative data are summarized in Table 1 . As shown in lane 1 of the figure, under multiple turnovers with $0.2 \mu \mathrm{M}$ enzyme, $50 \mu \mathrm{M}\left[{ }^{14} \mathrm{C}\right] \mathrm{IPP}$ and $50 \mu \mathrm{M}$ FPP, the $\mathrm{C}_{20}-\mathrm{C}_{40}$ products were formed. This is due to that the IPP condensation rate is slow $\left(\sim 0.005 \mathrm{~s}^{-1}\right)$ and FPP has a chance to displace the intermediates from the active site. Under the increased ratio of IPP to FPP (FPP concentration was reduced to $5 \mu \mathrm{M}$ ) as shown in lane $2, \mathrm{C}_{40}$ and very small amount of $\mathrm{C}_{45}$ were generated. The rate of $\mathrm{C}_{40}$ conversion to $\mathrm{C}_{45}$ was extremely slow $\left(2 \times 10^{-5} \mathrm{~s}^{-1}\right)$. No further elongated product larger than $\mathrm{C}_{45}$ could be observed even at high temperature $80{ }^{\circ} \mathrm{C}$ where OPPs has enhanced activity (data not shown). An OPPs reaction with [E.FPP] $>[$ IPP] was performed to monitor the product formation with limited amount of IPP. The reaction shown in lane 3 of the figure contained $10 \mu \mathrm{M}$ thermophilic OPPs, only $1 \mu \mathrm{M}\left[{ }^{14} \mathrm{C}\right] \mathrm{IPP}$ and excessive FPP $(50 \mu \mathrm{M})$. Under this condition where the E.FPP concentration was 10 -fold higher than that of IPP, $\mathrm{C}_{20}$-geanylgeranyl pyrophosphate was found as sole product. The result remained the same when the reaction was performed at $80{ }^{\circ} \mathrm{C}$ (data not shown). This represents an

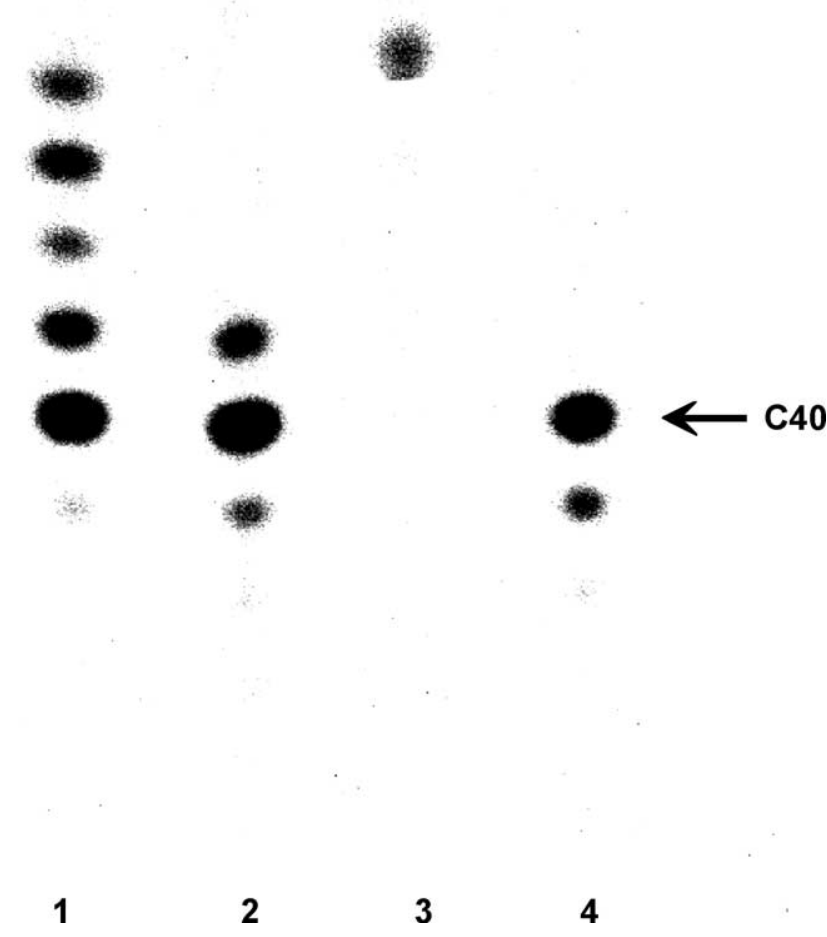

Fig. 6. The product distribution of T. maritima OPPs reaction using FPP and $\left[{ }^{14} \mathrm{C}\right] \mathrm{IPP}$ as substrates under various conditions for $100 \mathrm{~h}$ at $25^{\circ} \mathrm{C}$. The reaction conditions are lane $1: 0.2 \mu \mathrm{M}$ enzyme with $50 \mu \mathrm{M}\left[{ }^{14} \mathrm{C}\right] \mathrm{IPP}$ and 50 $\mu \mathrm{M}$ FPP; lane 2: $0.2 \mu \mathrm{M}$ enzyme with $50 \mu \mathrm{M}\left[{ }^{14} \mathrm{C}\right] \mathrm{IPP}$ and $5 \mu \mathrm{M}$ FPP; lane 3: $10 \mu \mathrm{M}$ enzyme with $1 \mu \mathrm{M}\left[{ }^{14} \mathrm{C}\right] \mathrm{IPP}$ and $50 \mu \mathrm{M}$ FPP; lane $4: 10 \mu \mathrm{M}$ enzyme with $1 \mu \mathrm{M}\left[{ }^{14} \mathrm{C}\right] \mathrm{IPP}$ and $0.1 \mu \mathrm{M}$ FPP.
Table 1

Product distribution of T. maritima OPPs catalyzed condensation reactions of IPP with FPP under various conditions

\begin{tabular}{lcccccc}
\hline Condition & \multicolumn{1}{c}{ Product (\%) } & & & \\
\cline { 2 - 7 } & $\mathrm{C}_{20}$ & $\mathrm{C}_{25}$ & $\mathrm{C}_{30}$ & $\mathrm{C}_{35}$ & $\mathrm{C}_{40}$ & $\mathrm{C}_{45}$ \\
\hline $0.2 \mu \mathrm{M}$ E; $50 \mu \mathrm{M}$ FPP; $50 \mu \mathrm{M}$ IPP & 28.0 & 22.3 & 7.6 & 11.9 & 28.3 & 1.8 \\
$0.2 \mu \mathrm{M}$ E; $5 \mu \mathrm{M}$ FPP; $50 \mu \mathrm{M}$ IPP & - & - & - & 20.7 & 72.5 & 6.9 \\
$10 \mu \mathrm{M}$ E; $50 \mu \mathrm{M}$ FPP; $1 \mu \mathrm{M}$ IPP & 100 & - & - & - & - & - \\
$10 \mu \mathrm{M}$ E; $0.1 \mu \mathrm{M}$ FPP; $1 \mu \mathrm{M}$ IPP & - & - & - & - & 87.2 & 12.8 \\
\hline
\end{tabular}

interesting difference between T. maritima OPPs and E. coli enzyme since the later generates $\mathrm{C}_{20}-\mathrm{C}_{40}$ as products under the same condition [14]. In a control reaction shown in lane $4, \mathrm{C}_{40}$ was synthesized by $10 \mu \mathrm{M}$ T. maritima enzyme when FPP concentration was reduced to $0.1 \mu \mathrm{M}$ and $\left[{ }^{14} \mathrm{C}\right] \mathrm{IPP}$ concentration remained as $1 \mu \mathrm{M}$.

\section{Discussion}

The OPPs encoding gene has been identified from the complete genome sequences of T. maritima using BLAST program [26]. This gave no firm answer regarding to the chain length of enzyme product as the sequence of $T$. maritima OPPs has $32 \%, 32 \%$ and $31 \%$ similarity with that of E. coli OPPs, Synechocystis sp. $\mathrm{C}_{45}$-solanesyl pyrophopshate synthase and Mycobacterium tuberculosis $\mathrm{C}_{35}$-heptaprenyl pyrophosphate synthase, respectively (Fig. 1). We identify in this study the product of this putative enzyme to be $\mathrm{C}_{40}$. In order to know how a thermophilic enzyme is different from the corresponding enzyme in a mesophile $(E$. coli), we conducted experiments to reveal the different properties of two enzymes at $25{ }^{\circ} \mathrm{C}$. The $k_{\text {cat }}$ value of the T. maritima OPPs reaction measured under steady-state condition is $0.005 \mathrm{~s}^{-1}$, consistent with the rate of IPP condensation obtained from enzyme single-turnover experiments. Therefore, the IPP condensation represents the ratelimiting step of the T. maritima OPPs reaction. In contrast, the IPP condensation catalyzed by E. coli OPPs is $2 \mathrm{~s}^{-1}$ and the product release (steady-state rate) is 100 -fold slower, indicating that the product release is rate determining. Despite the sequence homology between two enzymes, $T$. maritima OPPs has $10^{3}$ times lower activity in IPP condensation compared to E. coli OPPs at $25{ }^{\circ} \mathrm{C}$. However, with increased temperature, the T. maritima enzyme has elevated level of activity. The activity of OPPs in $T$. maritima at high temperature is required for biosynthesis of menaquinone as a putative 1,4-dihydroxy-2-naphthoate octaprenyltransferase is identified in the genome of the bacterium. Indeed, most Gram-positive bacteria and anaerobic Gram-negative bacteria contain only menaquinone [27]. The reason for causing 1000-fold lower activity in $T$. maritima OPPs at $25{ }^{\circ} \mathrm{C}$ must be due to a subtle change in the tertiary structure since the composition and secondary structure are similar for two enzymes. 
The rate for an extra IPP incorporation into OPP is 0.02 $\mathrm{s}^{-1}$ and products with excessive IPP molecules were observed for E. coli OPPs [14]. However, for T. maritima OPPs, it is almost negligible $\left(2 \times 10^{-5} \mathrm{~s}^{-1}\right)$ for the formation of $\mathrm{C}_{45}$ and the larger polymers than $\mathrm{C}_{45}$ are not observed even at high temperature where the T. maritima enzyme has higher activity. Apparently, T. maritima OPPs has higher product specificity compared to $E$. coli OPPs. Moreover, the product under the IPP single-turnover reaction of $10 \mu \mathrm{M} \mathrm{T}$. maritima OPPs.FPP complex with $1 \mu \mathrm{M}$ IPP is $\mathrm{C}_{20}$ geranylgeranyl pyrophosphate at $25^{\circ} \mathrm{C}$ and at high temperature $\left(80{ }^{\circ} \mathrm{C}\right)$. In contrast, E. coli OPPs produces $\mathrm{C}_{20}-\mathrm{C}_{40}$ compounds under the same condition. The intermediatebound OPPs from E. coli might undergo conformational change to increase its affinity with IPP leading to formation of product at lower concentration of IPP than OPPs.FPP. The undecaprenyl pyrophosphate synthase that shows similar pattern of product distribution has a flexible structure as a protein conformational change was observed during catalysis [28]. However, this unique phenomenon was not seen in T. maritima OPPs.

In summary, we have utilized a pre-steady-state method to analyze the complete kinetic pathway of $T$. maritima OPPs reaction, which was not previously determined. This kinetic pathway contains five IPP condensation steps with a rate of $\sim 0.005 \mathrm{~s}^{-1}$ for each step simulated from our kinetic data. Despite the similar secondary structure, the enzyme has lower enzyme activity at $25{ }^{\circ} \mathrm{C}$, higher product specificity, higher thermal stability and lower structural flexibility than its mesophilic E. coli counterpart.

\section{Acknowledgements}

This study was supported by a grant (NSC91-2113-M001-007) from National Council of Science of Taiwan and a grant from Academia Sinica.

\section{References}

[1] M.W.W. Adams, Enzymes and proteins from organisms that grow near and above 100 degrees Celsius, Annu. Rev. Microbiol. 47 (1993) $627-658$

[2] M.W. Day, B.T. Hsu, L. Joshua-Tor, J.B. Park, Z.H. Zhou, M.W. Adams, D.C. Rees, X-ray crystal structures of the oxidized and reduced forms of the rubredoxin from the marine hyperthermophilic archaebacterium Pyrococcus furiosus, Protein Sci. 1 (1992) 1494-1507.

[3] R. Huber, T.A. Langworthy, H. Konig, M. Thomm, C.R. Woese, U.B. Sleytr, K.O. Stetter, Thermotoga maritima sp. nov. represents a new genus of unique extremely thermophilic eubacteria growing up to $90{ }^{\circ} \mathrm{C}$, Arch. Microbiol. 144 (1986) 324-333.

[4] K. Ogura, T. Koyama, H. Sagami, Polyprenyl diphosphate synthases, Sub-cell. Biochem. 28 (1997) 57-87(Chapter 3).

[5] K. Ogura, T. Koyama, Enzymatic aspects of isoprenoid chain elongation, Chem. Rev. 98 (1998) 1263-1276.
[6] S. Fujisaki, T. Nishino, H. Katsuki, Isoprenoid synthesis in Escherichia coli. Separation and partial purification of four enzymes involved in the synthesis, J. Biochem. 99 (1986) 1327-1337.

[7] K.-I. Asai, S. Fujisaki, Y. Nishimura, T. Nishino, K. Okada, T. Nakagawa, M. Kawamukai, H. Matsuda, The identification of Escherichia coli ispB (cel) gene encoding the octaprenyl diphosphate synthase, Biochem. Biophys. Res. Commun. 202 (1994) 340-345.

[8] K. Okada, K. Suzuki, Y. Kamiya, X. Zhu, S. Fujisaki, Y. Nishimura, T. Nishino, T. Nakagawa, M. Kawamukai, H. Matsuda, Polyprenyl diphosphate synthase essentially defines the length of the side chain of ubiquinone, Biochim. Biophys. Acta 1302 (1996) 217-223.

[9] K. Okada, M. Minehira, X. Zhu, K. Suzuki, T. Nakagawa, H. Matsuda, M. Kawamukai, The $i \operatorname{sp} B$ gene encoding octaprenyl diphosphate synthase is essential for growth of Escherichia coli, J. Bacteriol. 179 (1997) 3058-3060.

[10] M.D. Collin, D. Jones, Distribution of isoprenoid quinone structural types in bacteria and their taxonomic implication, Microbiol. Rev. 45 (1981) 316-354.

[11] M.N. Ashby, P.A. Edwards, Elucidation of the deficiency in two yeast coenzyme Q mutants. Characterization of the structural gene encoding hexaprenyl pyrophosphate synthetase, J. Biol. Chem. 265 (1990) 13157-13164.

[12] H. Teclebrhan, J. Olsson, E. Swiezewska, G. Dallner, Biosynthesis of the side chain of ubiquinone:trans-prenyltransferase in rat liver microsomes, J. Biol. Chem. 268 (1993) 23081-23086.

[13] L. Ernster, G. Dallner, Biochemical, physiological and medical aspects of ubiquinone function, Biochim. Biophys. Acta 1271 (1995) 195-204.

[14] J.J. Pan, T.H. Kuo, Y.K. Chen, L.W. Yang, P.H. Liang, Insight into the activation mechanism of $E$. coli octaprenyl pyrophosphate synthase derived from pre-steady-state kinetic analysis, Biochim. Biophys. Acta 1594 (2002) 64-73.

[15] P.H. Liang, T.P. Ko, A.H.-J. Wang, Structure, mechanism and function of prenyltransferases, Eur. J. Biochem. 269 (2002) 3339-3354 (doi:10.1046/j.1432-1033.2002.03014.x).

[16] H. Fujii, T. Koyama, K. Ogura, Efficient enzymatic hydrolysis of polyprenyl pyrophosphate, Biochim. Biophys. Acta 712 (1982) 716-718.

[17] N. Shimizu, T. Koyama, K. Ogura, Molecular cloning, expression, and purification of undecaprenyl diphosphate synthase, J. Biol. Chem. 273 (1998) 19476-19481.

[18] B.A. Barshop, R.F. Wrenn, C. Frieden, Analysis of numerical methods for computer simulation of kinetic processes: development of KINSIM - a flexible, portable system, Anal. Biochem. 130 (1983) 134-145.

[19] P.F. Davison, Proteins in denaturing solvents: gel exclusion studies, Science 161 (1968) 906-907.

[20] N. Sreerama, R.W. Woody, A self-consistent method for the analysis of protein secondary structure from circular dichroism, Anal. Biochem. 209 (1993) 32-44.

[21] M.R. Eftink, Use of multiple spectroscopic methods to monitor equilibrium unfolding of proteins, Methods Enzymol. 259 (1995) 487-512.

[22] J.J. Pan, S.T. Chiu, P.H. Liang, Product distribution and pre-steadystate kinetic analysis of $E$. coli undecaprenyl pyrophosphate synthase, Biochemistry 39 (2000) 10936-10942.

[23] J.J. Pan, L.W. Yang, P.H. Liang, Effect of site-directed mutagenesis of the conserved aspartate and glutamate on E. coli undecaprenyl pyrophosphate synthase catalysis, Biochemistry 39 (2000) 13856-13861.

[24] T.P. Ko, Y.K. Chen, H. Robinson, P.C. Tsai, Y.G. Gao, A.P.-C. Chen, A.H.-J. Wang, P.H. Liang, Mechanism of the product chain length determination and the role of a flexible loop in undecaprenyl pyrophosphate synthase catalysis, J. Biol. Chem. 276 (2001) 47474-47486.

[25] T. Kainou, K. Okada, K. Suzuki, T. Nakagawa, H. Matsuda, M. Kawamukai, Dimer formation of octaprenyl-diphosphate synthase (IspB) is essential for chain length determination of ubiquinone, J. Biol. Chem. 276 (2001) 7876-7883.

[26] S.F. Altschul, T.L. Madden, A.A. Schaffer, J. Zhang, Z. Zhang, W. Miller, D.J. Lipman, Gapped BLAST and PSI-BLAST: a new gener- 
ation of protein database search program, Nucleic Acids Res. 25 (1997) 3389-3402.

[27] B. Soballe, R.K. Poole, Microbial ubiquinones: multiple roles in respiration, gene regulation and oxidative stress management, Microbiology 145 (1999) 1817-1830.
[28] Y.H. Chen, A.P.-C. Chen, C.T. Chen, A.H.-J. Wang, P.H. Liang, Probing the conformational change of Escherichia coli undecaprenyl pyrophosphate synthase during catalysis using an inhibitor and tryptophan mutants, J. Biol. Chem. 277 (2002) 7369-7376. 